CASSOWARY volume 4 (2) Juni 2021: 172-189

ISSN : 2614-8900

E-ISSN : 2622-6545

CProgram Pascasarjana Universitas Papua, https://pasca.unipa.ac.id/

\title{
Persepsi dan Partisipasi Masyarakat Adat atas Penetapan Kawa- san Cagar Alam Teluk Bintuni di Distrik Wamesa Kabupaten Teluk Bintuni
}

\author{
Syaiful Anwar Killian ${ }^{1 *}$, Selvi Tebaiy ${ }^{2}$, Ishak Musaad ${ }^{2}$ \\ ${ }^{1}$ Dinas Pertanian Kabupaten Teluk Bintuni, Jl Raya Bintuni, Kabupaten Teluk Bintuni, \\ 98364, Papua Barat, Indonesia \\ ${ }^{2}$ Program Studi Magister Ilmu Lingkungan Universitas Papua, Jl. Gunung Salju Amban \\ Manokwari, 98314, Papua Barat, Indonesia \\ *Email: syaifulkillian73@gmail.com
}

\begin{abstract}
The indigenous peoples who live and live in the Bintuni Bay Nature Reserve Area in Wamesa District, consist of three villages, namely Mamuranu, Anak Kasih and Wasari. The economic activities carried out by indigenous peoples in the Bintuni Bay Nature Reserve conservation area are very high. This is related to the type of work or livelihood that the community is engaged in, namely fishermen (fish, shrimp and $\mathrm{crab}$ ) at $43.75 \%$ and farming or gardening at $37.5 \%$. Meanwhile, the public perception of the determination of the Bintuni Bay nature reserve area is quite varied. For example, the perception regarding the desire for community involvement in forest conservation in the Bintuni Bay nature reserve is very high (83.75\%). Meanwhile, the perception of socialization or counseling from the Forestry Service / Agencies related to the management of the Bintuni Bay Nature Reserve is low (26.25\%). Regarding the management of the Bintuni Bay nature reserve area, in general the community hopes to be actively involved in activities related to the Bintuni Bay Nature Reserve Area. In addition, the community wants to be allowed to carry out economic activities in the area, such as labor, gardening, fishing and others. Meanwhile, for the Government, the community hopes that there will be efforts to improve the community's economy and increase infrastructure and other public facilities, but while maintaining environmental sustainability forest in the Bintuni Bay nature reserve area.
\end{abstract}

Keywords: Perception, Nature Reserve Areas, Economy.

\section{PENDAHULUAN}

Kabupaten Teluk Bintuni merupakan Kabupaten yang terletak di Provinsi Papua Barat berada diwilayah kepala burung Pulau New Guinea dengan potensi mangrove yang melimpah. Menurut Dinas Kehutanan dan Perkebunan Provinsi
Papua Barat, luas kawasan hutan mangrove di Provinsi Papua Barat mencapai 422.575,79 Ha. Area hutan mangrove yang terluas terdapat pada pesisir Kabupaten Teluk Bintuni dengan luas 236.176 Ha, kemudian diikuti oleh Kabupaten Sorong Selatan sebesar 75.333,80 Ha dan yang terakhir terdapat di Kabupaten 
Teluk Wondama dengan luasan yang hanya mencapai 427,32 Ha (Kusmana dan Sudarmadji, 2003).

Pertumbuhan penduduk yang tinggi dan meningkatnya kegiatan pembangunan di wilayah pesisir menyebabkan terjadinya tekanan ekologis terhadap ekosistem hutan mangrove. Meningkatnya tekanan ini akan berdampak terhadap kerusakan hutan mangrove baik secara langsung, seperti kegiatan penebangan dan konversi lahan maupun secara tidak langsung, seperti pencemaran atau limbah berbagai kegiatan pembangunan pelabuhan. Berdasarkan data dari Kelompok Kerja Mangrove Daerah Papua Barat (2012), bahwa kerusakan hutan mangrove di Kabupaten Teluk Bintuni mencapai 8.553,03 Ha.

Hutan mangrove sebagai salah satu ekosistem wilayah pesisir dan lautan yang sangat potensial bagi kesejahteraan masyarakat baik dari segi ekonomi, sosial dan lingkungan hidup (Karuniastuti, 2013). Sebagai upaya untuk melindungi keberadaan Hutan Mangrove, Pemerintah melalui SK Menteri Kehutanan nomor : 3121/MenhutVII/KUH/2014 tanggal 24 April 2014 telah menetapkan kawasan hutan mangrove di Kabupaten Teluk Bintuni seluas135.101,59 hektar sebagai Kawasan Cagar Alam.

Hutan Mangrove di Kabupaten Teluk Bintuni selain berfungsi sebagai habitat penting bagi fauna yang bernilai ekonomis, namun juga menjadi tempat hidup bagi sebagian masyarakat Teluk Bintuni. Hal ini ditandai dengan adanya perkampungan yang berada di dalam dan sekitar kawasan cagar alam Teluk Bintuni. Pada tahun 2005 tercatat sekitar 14 kampung dengan jumlah penduduk sebanyak 9.557 jiwa, dimana sebagian besar masyarakatnya bermata pencaharian sebagai nelayan, berburu, meramu dan perladangan (Sihite, dkk.,2005).
Berdasarkan regulasi (UU Nomor 05 Tahun 1990) yang tidak membolehkan adanya kegiatan apa pun di dalam kawasan cagar alam, selain kegiatan penelitian. Sehingga terdapat dua kepentingan yang berbeda. Di satu sisi masyarakat ingin tetap memanfaatkan sumber daya yang ada di dalam kawasan sedangkan Pemerintah berkewajiban untuk menjaga kelestarian Cagar Alam Teluk Bintuni.

Status Kawasan Cagar Alam Teluk Bintuni telah ditetapkan oleh pemerintah, sehingga akan membatasi aktivitas masyarakat pada kawasan tersebut, termasuk aktivitas ekonomi. Oleh karena itu perlu dilakukan penelitian untuk mengetahui persepsi masyarakat yang berada dalam Kawasan Cagar Alam di Kabupaten Teluk Bintuni. Selanjutnya hasil penelitian ini dapat menjadi bahan masukan bagi penyusunan kebijakan pemerintah, sehingga potensi konflik antara masyarakat terutama pemilik hak ulayat dan pemerintah dapat dihindari. Untuk itu maka kebijakan Pemerintah sangat diperlukan dalam rangka memberikan pengakuan terhadap keberadaan dan hak-hak masyarakat adat atas Kawasan konservasi cagar alam Teluk Bintuni.

\section{MATERI DAN METODE}

\section{Waktu dan Tempat Penelitian}

Penelitian ini dilaksanakan pada bulan September tahun 2020 dengan lokasi penelitian di Kampung Mamuranu, Kampung Anak kasih dan Kampung Wasari Distrik Wamesa Kabupaten Teluk Bintuni.

\section{Metode Penelitian}

Metode yang digunakan dalam penelitian ini adalah metode deskriptif kualitatif. Menurut Nawawi dan Martini (1996), Penelitian Deskriptif Kualitatif adalah penelitian yang menggambarkan 
atau melukiskan obyek penelitian berdasarkan fakta-fakta yang tampak atau sebagaimana adanya. Penelitian Deskriptif berusaha mendeskripsikan seluruh gejala atau keadaan yang ada, yaitu keadaan gejala menurut apa adanya pada saat penelitian dilakukan (Mukhtar, 2013).

\section{Analisis Data}

Pengolahan data dari hasil wawancara pada kuesioner dilakukan kedalam bentuk tabulasi, kemudian dianalisis dengan tehnik skoring dan secara deskriptif. Tehnik skoring digunakan untuk mengukur tingkat persepsi masyarakat, analisis deskriptif digunakan untuk menggambarkan karakteristik responden dan faktor-faktor yang diasumsikan berpengaruh terhadap persepsi.

Proses penentuan skor atas jawaban responden yang dilakukan dengan membuat klasifikasi dan kategori yang cocok tergantung anggapan atau opini responden. Sedangkan penghitungan scoring dilakukan dengan menggunakan skala Likert yang pengukurannya sebagai berikut (Riduwan, 2009):

a. Skor 5 untuk jawaban sangat setuju

b. Skor 4 untuk jawaban setuju

c. Skor 3 untuk jawaban ragu-ragu

d. Skor 2 untuk jawaban tidak setuju

e. Skor 1 untuk jawaban sangat tidak setuju

Menurut Riduwan (2009), Skala Likert digunakan untuk mengukur sikap, pendapat dan persepsi sesorang atau sekelompok orang tentang fenomena sosial. Skala likert biasanya digunakan untuk pengukuran perilaku yang terdiri dari pernyataan dan disertai jawaban setuju - tidak setuju, sering - tidak pernah, cepat - lambat, baik - buruk dan lainnya. Dalam penelitian ini skala likert digunakan untuk mengukur persepsi masyarakat tentang kawasan cagar alam Teluk Bintuni.
Skor ideal merupakan skor yang digunakan untuk menghitung skor untuk menentukan rating skala dan jumlah seluruh jawaban. Untuk menghitung jumlah skor ideal (kriterium) dari seluruh item digunakan rumus berikut, yaitu :

Skor Kriterium $=$ Nilai Skala $\mathrm{x}$ Jumlah Responden

Selanjutnya skor yang telah diperoleh kemudian dimasukan ke dalam rating skala. Rating sakala berfungsi untuk mengetahui hasil data angket (kuesioner) dan wawancara umum dan keseluruhan yang di dapat dari penilaian angket.

Sedangkan untuk mengetahui jumlah jawaban dari para responden melalui presentase, yaitu digunakan rumus sebagai berikut (Sugiono, 2012):

$$
\mathrm{p}=(\mathrm{f} / \mathrm{n}) \times 100 \%
$$

Keterangan :

$\mathrm{p}=$ Prosentase

$\mathrm{f} \quad=$ Frekuensi dari setiap jawaban angket

$\mathrm{n}=$ Jumlah skor ideal

\section{HASIL DAN PEMBAHASAN}

\section{Gambaran Umum Lokasi Penelitian}

Lokasi penelitian berada di tiga kampung, Distrik Wamesa, yaitu kampung Mamuranu, Anak Kasih dan Wasari. Secara umum Distrik Wamesa memiliki luas wilayah sebesar $816 \mathrm{~km} 2$. Distrik ini terbagi menjadi 6 (enam) kampung yang secara umum berada di daerah pesisir, dimana sebagian di daerah pantai dan sebagian lagi di daerah dataran rata.Secara geografis, Distrik Wamesa Kabupaten Teluk Bintuni memiliki batas wilayah sebagai berikut: 
Sebelah Utara : Berbatasan dengan Distrik Manimeri

Sebelah Selatan: Berbatasan dengan Kabupaten Teluk Wondama

Sebelah Barat : Berbatasan dengan Distrik Kuri

Sebelah Timur : Berbatasan dengan Kabupaten Teluk Wondama

Berdasarkan data BPS, Penduduk Distrik Wamesa pada tahun 2019 tercatat sebanyak 1.204 jiwa yang terdiri dari 629 laki-laki dan 575 perempuan. Wilayah Distrik Wamesa, berdasarkan SK Menteri Kehutanan No: 891/KPTSII/1999 ternyata masuk dalam Kawasan Cagar Alam Teluk Bintuni yang memiliki luas sebesar $124.850 \mathrm{Ha}$, dimana lebih dari $90 \%$ merupakan ekosistem Hutan Mangrove (Hasil Survey Tim TNC, 2005).

Kawasan Cagar Alam Teluk Bintuni (CATB) merupakan daerah konservasi yang memiliki kekhasan dengan ekosistem mangrove yang utuh dan unik sehinga perlu di lindungi keberadaannya. Selain memiliki fungsi perlindungan bagi flora fauna, Cagar Alam Teluk Bintuni juga memiliki fungsi sosial ekonomi bagi masyarakat di sekitar maupun di dalam kawasan. Manfaat yang diambil oleh masyarakat dari kawasan Cagar Alam Teluk Bintuni umumnya adalah produk non kayu, terutama hasil perikanan (Sihite, dkk. 2005).

\section{Tingkat Pengetahuan Masyarakat terhadap kawasan Cagar Alam Teluk Bintuni}

Berdasarkan hasil penelitian ternyata diketahui bahwa tingkat pengetahuan masyarakat setempat terhadap kawasan cagar alam sangat rendah. Dari hasil wawancara, $75 \%$ responden mengaku tidak pernah tahu tentang kawasan cagar alam dan hanya $25 \%$ yang mengaku mengetahui kawasan cagar alam. Bahkan ironisnya, sebagian besar masyarakat $(56 \%)$ tidak mengetahui jika kampung tempat mereka tinggal masuk dalam kawasam konservasi cagar alam Teluk Bintuni. Hal ini disebabkan sosialisasi yang rendah dari instansi terkait. Meskipun demikian, seluruh responden $(100 \%)$ sadar pentingnya fungsi hutan terhadap kehidupan manusia, sehingga perlu dan harus dijaga dengan baik.

Keberadaan kampung-kampung yang berada dalam kawasan Cagar Alam Teluk Bintuni sudah lama terjadi, bahkan ada kampung terutama kampung Mamuranu yang sudah ada sebelum adanya penunjukkan Cagar Alam Teluk Bintuni. Dengaan keberadaan kampung tersebut, maka aktivitas masyarakat sehari-hari akan sangat tergantung pada sumber daya alam yang ada dalam Cagar Alam Teluk Bintuni (Sihite, dkk. 2005).

Terkait keberadaan instansi yang mengelola kawasan Cagar Alam Teluk Bintuni, tercatat sebanyak $68,75 \%$ responden yang mengaku tidak mengetahuinya. Bahkan 18,75\% mengatakan bahwa tidak ada instansi yang mengelola kawasan Cagar Alam dan hanya $12,5 \%$ responden yang mengakui adanya instansi yang mengelola kawasan tersebut, namun tidak tahu nama instansinya. Terkait aktivitas penebangan hutan yang dilakukan oleh perusahaan dalam kawasan, sebanyak 37,5\% mengaku ada penebangan hutan oleh perusahaan. Sedangkan $43,75 \%$ mengaku tidak tahu dan hanya $18,75 \%$ yang menjawab tidak ada aktivitas penebangan oleh pihak perusahaan. 
Tabel 1. Tanggapan masyarakat Distrik Wamesa terhadap keberadaan Kawasan Cagar Alam Teluk Bintuni

\begin{tabular}{|c|c|c|c|c|c|}
\hline \multirow[b]{2}{*}{ No. } & \multirow[b]{2}{*}{ Pertanyaan } & \multicolumn{2}{|c|}{ Jawaban Responden } & \multicolumn{2}{|c|}{ Presentase } \\
\hline & & Pernah & $\begin{array}{l}\text { Tidak } \\
\text { Pernah }\end{array}$ & Pernah & $\begin{array}{l}\text { Tidak } \\
\text { Pernah }\end{array}$ \\
\hline 1 & $\begin{array}{l}\text { Apakah Bapak/Ibu pernah menerima infor- } \\
\text { masi tentang Kawasan Cagar Alam Teluk Bin- } \\
\text { tuni? }\end{array}$ & 4 & 12 & $25,00 \%$ & $75,00 \%$ \\
\hline 2. & $\begin{array}{l}\text { Apakah Bapak/Ibu pernah menerima ganti } \\
\text { rugi/ kompensasi dari pemerintah sehubungan } \\
\text { dengan penetapan Kawasan Cagar Alam Te- } \\
\text { luk Bintuni? }\end{array}$ & 0 & 16 & $0,00 \%$ & $100,00 \%$ \\
\hline 3 & $\begin{array}{l}\text { Apakah bapak/Ibu mengetahui bahwa kawa- } \\
\text { san cagar alam merupakan daerah konservasi } \\
\text { yang dilindungi? }\end{array}$ & 5 & 11 & $31,25 \%$ & $68,75 \%$ \\
\hline 4 & $\begin{array}{l}\text { Apakah Bapak/Ibu tahu/ mengerti, apa yang } \\
\text { dimaksud dengan konservasi? }\end{array}$ & 2 & 14 & $12,50 \%$ & $87,50 \%$ \\
\hline 5 & $\begin{array}{l}\text { Apakah Bapak/Ibu mengetahui bahwa Kam- } \\
\text { pung yang ditinggali saat ini sudah masuk da- } \\
\text { lam Kawasan Cagar Alam Teluk Bintuni ? }\end{array}$ & 7 & 9 & $43,75 \%$ & $56,25 \%$ \\
\hline 6 & $\begin{array}{l}\text { Untuk membangun rumah/ bangunan lainnya } \\
\text { di kampung, apakah Bapak/ibu menggunakan } \\
\text { kayu yang berasal dari Hutan Mangrove? }\end{array}$ & 16 & & $100,00 \%$ & \\
\hline
\end{tabular}

Berdasarkan hasil penelitian di Tabel 1 diketahui bahwa seluruh responden (100\%) yang merupakan pemilik hak ulayat mengaku tidak pernah menerima kompensasi/ ganti rugi dari pemerintah terkait penetapan kawasan cagar alam Teluk Bintuni. Karena ketidaktahuan masyarakat, seluruh responden (100\%) mengaku menggunakan kayu yang berasal dari hutan mangrove untuk membangun rumah maupun infrastruktur lainnya di kampung. Padahal dalam kawasan cagar alam sangat dilarang untuk melakukan aktivitas apa pun yang dapat mengakibatkan kerusakan hutan.

Hal ini sesuai dengan pendapat Sihite, dkk (2005) bahwa penambahan jumlah penduduk yang tinggal di kawasan Cagar Alam Teluk Bintuni akan menyebabkan semakin besar sumber daya alam yang akan diambil yang selanjutnya menyebabkan jumlah dan jenis Flora maupun fauna di dalam kawasan Cagar Alam Teluk Bintuni semakin menurun.

\section{Persepsi Masyarakat Terhadap Ka- wasan Cagar Alam Teluk Bintuni}

Persepsi masyarakat Kampung Anakasih, Wasari dan Mamuranu terhadap Kawasan Cagar Alam Teluk Bintuni dapat digolongkan ke dalam kategori persepsi baik. Hal ini sesuai dengan pernyataan Ngakan, dkk (2006) yang menyatakan bahwa persepsi baik, apabila mereka memahami dengan baik bahwa dirinya bergantung hidup dari sumberdaya hayati hutan dan menginginkan agar sumberdaya tersebut dikelolasecara lestari.

Berdasarkan hasil penelitian diketahui bahwa seluruh responden masih sangat tergantung terhadap keberadaan kawasan Cagar Alam Teluk Bintuni. Mayoritas pekerjaan masyarakat ialah sebagai petani dan nelayan sehingga masyarakat masih memanfaatkan kawasan Cagar Alam sebagai mata pencaharian mereka. Selain itu masyarakat di tiga kampung tersebut sudah turun temurun tinggal dalam kawasan Cagar Alam Teluk Bintuni.

Dari hasil penelitian diketahui bahwa aktivitas masyarakat yang tinggal dalam 
kawasan Cagar Alam Teluk Bintuni sangat tinggi. Sebagian besar responsen (56\%) mengaku setiap hari melakukan aktivitasnya dalam kawasan Cagar Alam. Dan hanya 6\% responden yang menjawab dua minggu sekali melaksanakan aktivitas dalam kawasan Cagar Alam Teluk Bintuni. Hal ini dikarenakan penduduk yang berada dalam kawasan Cagar Alam secara turun temurun telah memanfaatkan Sumber Daya Alam baik Flora maupun Fauna. Namun pemanfaatannya lebih fokus kepada pemenuhan kebutuhan hidup. Pemanfaatan tanaman hutan oleh masyarakat lebih tertuju pada kayu sebagai bahan bakar dan juga bahan bangunan. Sedangkan pemanfataan Fauna lebih diutamakan pada fauna perairan, seperti ikan, kepiting, udang dan kerang/bia (Sihite, dkk. 2005).

Masyarakat mengakui masih memiliki kepentingan sangat tinggi terhadap sumber daya kawasan cagar alam baik secara langsung maupun tidak langsung antara lain sebagai sumber mata air, penghasil udara yang bersih, berburu, mencari ikan, udang, kepiting dan bahkan sebagai lokasi untuk bertani/ berkebun. Pentingnya keberadaan Kawasan Cagar Alam Teluk Bintuni bagi masyarakat, sehingga persepsi terhadap pelestarian kawasan sangat tinggi.

Berdasarkan hasil penelitian diketahui bahwa sebagian responden (56\%) mengaku bahwa hutan dalam kawasan cagar alam teluk bintuni sebagai tempat untuk mencari penghasilan. Hanya sedikit (6\%) responden yang menjawab fungsi hutan sebagai tempat menyimpan air. Hal ini senada dengan hasil penelitian Sihite, dkk (2005) yang menyebutkan bahwa pola interaksi masya-rakat dalam kawasan Cagar Alam Teluk Bintuni adalah dalam bentuk sumber mata pencaharian. Sebagian masyarakat bermata pencaharian sebagai nelayan, berburu dan menokok sagu. Jenis Fauna yang ada di dalam kawasan Cagar Alam Teluk Bintuni seperti buaya, rusa, babi dan beberapa jenis burung banyak dimanfaatkan oleh masyarakat sebagai hewan buruan. Perburuan satwa tersebut sudah menjadi sumber mata pencaharian di beberapa kampung di dalam maupun sekitar kawasan, seperti Naramasa, Yakati, Yensei, Mamuranu, Anak Kasih dan Tirasai. Buaya diambil kulitnya, sedangkan rusa dan babi diambil dagingnya untuk dibuat dendeng. Selain itu sumber daya alam hutan mangrove berupa lahan pada daerah peralihan telah dimanfaatkan sebagai kebun. Kegiatan pemanfaatan tersebut telah terjadi sejak jaman dahulu (Sihite, dkk. 2005).

\section{Persepsi terkait keterlibatan masyarakat dalam pelestarian hutan di kawasan Cagar Alam Teluk Bintuni}

Berdasarkan hasil penelitian, sebagian masyarakat menyadari jika wilayahnya masuk dalam kawasan cagar alam teluk Bintuni. Selain itu masyarakat memiliki keinginan kuat agar dapat dilibatkan oleh Pemerintah dalam upaya pelestarian hutan.

Tabel 2. Tanggapan Responden terkait keterlibatan masyarakat dalam pelestarian hutan

\begin{tabular}{|c|c|c|c|c|}
\hline \multirow[b]{2}{*}{$\begin{array}{c}\text { Alternatif } \\
\text { Jawaban }\end{array}$} & \multirow{2}{*}{$\begin{array}{c}\text { Al- } \\
\text { ter- } \\
\text { natif } \\
\text { Skor }\end{array}$} & \multicolumn{2}{|c|}{ Responden } & \multirow{2}{*}{$\begin{array}{c}\text { To- } \\
\text { tal } \\
\text { Skor }\end{array}$} \\
\hline & & $\begin{array}{c}\text { Jum- } \\
\text { lah }\end{array}$ & $\begin{array}{l}\text { Presen- } \\
\text { tase }\end{array}$ & \\
\hline $\begin{array}{l}\text { Sangat } \\
\text { Setuju }\end{array}$ & 5 & 6 & $37,50 \%$ & 30 \\
\hline Setuju & 4 & 7 & $43,75 \%$ & 28 \\
\hline Ragu-ragu & 3 & 3 & $18,75 \%$ & 9 \\
\hline $\begin{array}{l}\text { Tidak Set- } \\
\text { uju }\end{array}$ & 2 & 0 & $0,00 \%$ & 0 \\
\hline $\begin{array}{l}\text { Sangat } \\
\text { tidak set- } \\
\text { uju }\end{array}$ & 1 & 0 & $0,00 \%$ & 0 \\
\hline Total & & 16 & $100 \%$ & 67 \\
\hline
\end{tabular}

Hasil penelitian pada Tabel 2. menunjukkan bahwa $81,25 \%$ responden setuju 
dan sangat setuju jika pemerintah mau melibatkan masyarakat dalam upaya pelestarian hutan dalam kawasan Cagar Alam Teluk Bintuni. Meskipun terdapat sekitar $18,75 \%$ responden yang mengaku masih ragu-ragu dengan pernyataan tersebut.

Total skor yang diperoleh dari 16 responden pada indikator pernyataan sebesar 67. Sehingga angka indeks persepsi masyarakat terhadap pernyataan ini, yaitu : $67 / 80 \times 100 \%=83,75 \%$ atau tergolong sangat tinggi. Karena keterlibatan masyarakat dalam peletarian hutan dalam kawasan cagar alam merupakan salah satu keinginan masyarakat setempat.

\section{Persepsi terhadap ketergantungan masyarakat terhadap kawasan Cagar Alam Teluk Bintuni}

Masyarakat yang hidup di sekitar dan di dalam kawasan ternyata memiliki ketergantungan yang cukup besar terhadap keberadaan kawasan cagar alam Teluk Bintuni. Hampir seluruh kebutuhan hidup masyarakat di supplay oleh ketersediaan sumber daya alam yang ada. Karena sebagian besar masyarakat memiliki mata pencaharian sebagai nelayan, petani/ peramu maupun berburu.

Tabel 3. Tanggapan responden terhadap ketergantungan masyarakat terhadap Cagar Alam Teluk Bintuni

\begin{tabular}{lcccc}
\hline \multirow{2}{*}{$\begin{array}{c}\text { Alternatif } \\
\text { Jawaban }\end{array}$} & $\begin{array}{c}\text { Al- } \\
\text { ter- } \\
\text { natif } \\
\text { Skor }\end{array}$ & $\begin{array}{c}\text { Jum- } \\
\text { Sah }\end{array}$ & $\begin{array}{c}\text { Presen- } \\
\text { tase }\end{array}$ & $\begin{array}{c}\text { To- } \\
\text { tal } \\
\text { Skor }\end{array}$ \\
\hline Sangat & 5 & 9 & $56,25 \%$ & \\
Besar & & & & 45 \\
Besar & 4 & 7 & $43,75 \%$ & 28 \\
Cukup & 3 & 0 & $0,00 \%$ & 0 \\
Kecil & 2 & 0 & $0,00 \%$ & 0 \\
Sangat & 1 & 0 & $0,00 \%$ & \\
Kecil & & & & 0 \\
\hline \multicolumn{1}{c}{ Total } & & $\mathbf{1 6}$ & $\mathbf{1 0 0 \%}$ & $\mathbf{7 3}$ \\
\hline
\end{tabular}

Dari hasil penelitian pada Tabel 3 terungkap bahwa ketergantungan masyarakat terhadap keberadaaan kawasan cagar alam Teluk Bintuni sangat tinggi. Sekitar $56,25 \%$ menjawab sangat besar dan $43,75 \%$ menjawab cukup besar. Sedangkan total skor yang diperoleh dari 16 responden pada indikator pernyataan sebesar 73. Sehingga angka indeks persepsi masyarakat terhadap pernyataan ini, yaitu $73 / 80 \times 100 \%=91,25 \%$ atau tergolong sangat tinggi.

\section{Persepsi terhadap aktivitas masyara- kat di dalam kawasan cagar alam te- luk Bintuni}

Ketergantungan masyarakat terhadap kawasan cagar alam teluk Bintuni ditandai oleh tingginya aktivitas masyarakat di dalam kawasan, seperti bertani, berburuh, memancing, tangkap udang, kepiting dan lainnya.Selain itu masyarakat mengakui bahwa sebagian besar penghasilan berasal dari kawasan cagar alam, meskipun secara nominal masih dinilai belum cukup untuk memenuhi kebutuhan sehari-hari.

Tabel 4. Tanggapan Responden Terhadap Aktivitas Masyarakat di dalam kawasan Cagar Alam Teluk Bintuni

\begin{tabular}{|c|c|c|c|c|}
\hline \multirow{2}{*}{$\begin{array}{c}\text { Alter- } \\
\text { natif Ja- } \\
\text { waban }\end{array}$} & \multirow{2}{*}{$\begin{array}{c}\text { Al- } \\
\text { ter- } \\
\text { natif } \\
\text { Skor }\end{array}$} & \multicolumn{2}{|c|}{ Responden } & \multirow{2}{*}{$\begin{array}{c}\text { To- } \\
\text { tal } \\
\text { Skor }\end{array}$} \\
\hline & & $\begin{array}{l}\text { Jum- } \\
\text { lah }\end{array}$ & $\begin{array}{l}\text { Presen- } \\
\text { tase }\end{array}$ & \\
\hline Sangat & 1 & 8 & $50,00 \%$ & \\
\hline Sering & & & & 8 \\
\hline Sering & 2 & 8 & $50,00 \%$ & 16 \\
\hline $\begin{array}{l}\text { Ragu- } \\
\text { ragu }\end{array}$ & 3 & 0 & $0,00 \%$ & 0 \\
\hline Jarang & 4 & 0 & $0,00 \%$ & 0 \\
\hline Tidak & 5 & 0 & $0,00 \%$ & \\
\hline Pernah & & & & 0 \\
\hline Total & & 16 & $100 \%$ & 24 \\
\hline
\end{tabular}

Dari hasil penelitian yang disajikan pada Tabel 4 diketahui bahwa aktivitas masyarakat dalam kawasan hutan cagar alam Teluk Bintuni sangat tinggi. Tercatat sebanyak $50 \%$ responden mengaku sangat sering dan 50\% responden lainnya mengaku sering. Aktivitas yang biasa dilakukan, antara lain perburuan 
binatang liar maupun memancing, menangkap kepiting dan udang. Sedangkan total skor yang diperoleh dari 16 responden pada indikator pernyataan sebesar 24. Sehingga angka indeks persepsi masyarakat terhadap pernyataan ini, yaitu $24 / 80 \times 100 \%=80 \%$ atau tergolong rendah. Hal ini menunjukkan bahwa masyarakat pada prinsipnya tidak ingin kebiasaan yang sudah dilakukan secara turun temurun diganggu atau dihalangi. Meskipun tingginya aktivitas masyarakat dalam kawasan dalam berdampak merusak kelestarian kawasan cagar alam itu sendiri.

\section{Persepsi terkait Larangan Pemerintah terhadap masyarakat yang melakukan aktivitas (menebang pohon, berladang, memancing, ber- buruh) di dalam kawasan cagar alam teluk bintuni}

Cagar Alam merupakan suatu kawasan suaka alam yang karena keadaan alamnya mempunyai ke-khasan tumbuhan, satwa, dan ekosistemnya atau ekosistem tertentu yang perlu dilindungi dan perkembangannya berlangsung secara alami. Oleh karena itu aktivitas dalam kawasan cagar alam sesungguhnya sangat dibatasi.

Berdasarkan Undang-Undang Nomor 05 Tahun 1990 tentang Konservasi Sumber Daya Alam Hayati Dan Ekosistemnya menjelaskan secara detail fungsi cagar alam beserta larangannya.

Pada Pasal 21 ayat 1 pada UU No 5 tahun 1990, bahwa di dalam cagar alam yang merupakan bagian dari kawasan suaka alam, setiap orang dilarang untuk :

a. Mengambil, menebang, memiliki, merusak, memusnahkan, memelihara, mengangkut, dan memperniagakan tumbuhan yang dilindungi atau bagianbagiannya dalam keadaan hidup atau mati;

b. Mengeluarkan tumbuhan yang dilindungi atau bagian-bagiannya dalam keadaan hidup atau mati dari suatu tempat di Indonesia ke tempat lain di dalam atau di luar Indonesia.

Namun regulasi tersebut bertolak belakang dengan fakta yang ditemui masyarakat. Karena masyarakat yang berada di beberapa kampung Distrik Wamesa sudah sejak lama tinggal dan beraktivitas di dalam kawasan cagar alam teluk Bintuni. Bahkan sebagian besar masyarakat mengaku tidak mengetahui tentang regulasi yang mengatur tentang penetapan kawasan cagar alam Teluk Bintuni.

Tabel 5. Tanggapan Rersponden terhadap Larangan pemerintah melakukan aktivitas di dalam kawasan cagar alam

\begin{tabular}{|c|c|c|c|c|}
\hline \multirow{2}{*}{$\begin{array}{c}\text { Alternatif } \\
\text { Jawaban }\end{array}$} & \multirow{2}{*}{$\begin{array}{l}\text { Al- } \\
\text { ter- } \\
\text { natif } \\
\text { Skor }\end{array}$} & \multicolumn{2}{|c|}{ Responden } & \multirow{2}{*}{$\begin{array}{c}\text { To- } \\
\text { tal } \\
\text { Skor }\end{array}$} \\
\hline & & $\begin{array}{l}\text { Jum- } \\
\text { lah }\end{array}$ & $\begin{array}{c}\text { Presen- } \\
\text { tase }\end{array}$ & \\
\hline Sangat & 5 & 2 & $12,50 \%$ & \\
\hline Setuju & & & & 10 \\
\hline Setuju & 4 & 3 & $18,75 \%$ & 12 \\
\hline Ragu-ragu & 3 & 4 & $25,00 \%$ & 12 \\
\hline $\begin{array}{l}\text { Tidak Set- } \\
\text { uju }\end{array}$ & 2 & 7 & $43,75 \%$ & 14 \\
\hline $\begin{array}{l}\text { Sangat } \\
\text { Tidak Set- } \\
\text { uju }\end{array}$ & 1 & 0 & $0,00 \%$ & 0 \\
\hline Total & & 16 & $100 \%$ & 48 \\
\hline
\end{tabular}

Dari hasil penelitian pada Tabel 5 diketahui bahwa sebanyak $43,75 \%$ responden mengaku tidak setuju jika pemerintah melarang masyarakat untuk beraktivitas di dalam kawasan cagar alam Teluk Bintuni. Sementara 25\% responden mengaku ragu-ragu.

Total skor yang diperoleh dari 16 responden pada indikator pernyataan ini adalah sebesar 48. Sehingga angka indeks persepsi masyarakat adalah $48 / 80 \times 100 \%=60 \%$ atau tergolong sedang. Karena masyarakat dihadapkan pada dua pilihan yang sulit (dilematis), dimana kehidupan masyarakat selama ini sangat tergantung pada ketersediaan sumber daya 
alam di hutan, sementara di sisi lain $\mathrm{Hu}-$ tan/ kawasan tempat mencari penghasilan merupakan kawasan suaka alam yang harus dilindungi, dijaga, dilestarikan dan tidak boleh ada aktivitas di dalamnya.

\section{Persepsi terhadap peningkatan pem- bangunan di dalam kawasan cagar alam Teluk Bintuni}

Keberadaan tiga Kampung di Distrik Wamesa yang berada di dalam kawasan cagar alam teluk bintuni memberikan pilihan yang sulit bagi pemerintah, khususnya pemerintah Kabupaten Teluk Bintuni. Karena masyarakat yang hidup dan tinggal di wilayah tersebut sangat membutuhkan sentuhan pemerintah berupa pembangunan yang lebih baik, seperti perbaikan jalan, peningkatan fasilitas umum, peningkatan pemukiman penduduk dan lain-lain. Namun disisi lain, kawasan yang masyarakat tersebut tempati merupakan kawasan cagar alam yang tidak boleh diganggu keberadaannya sesuai Undangundang Nomor 5 tahun 1990 tentang Konservasi Sumber Daya Alam Hayati Dan Ekosistemnya.

Tabel 6. Tanggapan Responden jika pemerintah melakukan pembangunan di dalam kawasan cagar alam Teluk Bintuni

\begin{tabular}{|c|c|c|c|c|}
\hline \multirow{2}{*}{$\begin{array}{l}\text { Alternatif } \\
\text { Jawaban }\end{array}$} & \multirow{2}{*}{$\begin{array}{c}\text { Al- } \\
\text { ter- } \\
\text { natif } \\
\text { Skor }\end{array}$} & \multicolumn{2}{|c|}{ Responden } & \multirow{2}{*}{$\begin{array}{c}\text { To- } \\
\text { tal } \\
\text { Skor }\end{array}$} \\
\hline & & $\begin{array}{c}\text { Jum- } \\
\text { lah }\end{array}$ & $\begin{array}{l}\text { Presen- } \\
\text { tase }\end{array}$ & \\
\hline $\begin{array}{l}\text { Sangat } \\
\text { Setuju }\end{array}$ & 1 & 3 & $18,75 \%$ & 3 \\
\hline Setuju & 2 & 7 & $43,75 \%$ & 14 \\
\hline Ragu-ragu & 3 & 6 & $37,50 \%$ & 18 \\
\hline $\begin{array}{l}\text { Tidak Set- } \\
\text { uju }\end{array}$ & 4 & 0 & $0,00 \%$ & 0 \\
\hline $\begin{array}{l}\text { Sangat } \\
\text { Tidak Set- } \\
\text { uju }\end{array}$ & 5 & 0 & $0,00 \%$ & 0 \\
\hline Total & & 16 & $100 \%$ & 35 \\
\hline
\end{tabular}

Tabel 6 terungkap bahwa sekitar $62,5 \%$ responden mengaku setuju dan sangat setuju pemerintah melakukan pembangunan di wilayahnya, meskipun masuk dalam kawasan cagar alam Teluk Bintuni. Sementara hanya $37,5 \%$ responden yang menyatakan ragu-ragu. Total skor yang diperoleh dari 16 responden pada pernyataan tersebut adalah 35 , sehingga angka indeks persepsi menjadi $35 / 80 \times 100 \%=43,75 \%$ atau tergolong sedang. Karena adanya pembangunan di tempat yang ditinggali merupakan keinginan masyarakat agar dapat meningkatkan kesejahteraan.

Dari hasil wawancara dengan responden, bahwa fasilitas yang tersedia di kampung-kampung yang berada dalam kawasan cagar alam sangat terbatas. Sehingga diperlukan pembangunan infrastruktus, seperti sekolah, fasilitas kesehatan, jalan, jembatan hingga perumahan yang layak untuk masyarakat. Selain itu masyarakat membutuhkan peningkatan ekonomi melalui penambahan pendapatan keluarga, terutama dari sektor pertanian dan perikanan. Karena pada umumnya masyarakat yang tinggal di kampungkampung yang berada dalam kawasan cagar alam termasuk golongan ekonomi rendah dengan pendapatan di bawah garis kemiskinan.

Keinginan masyarakat untuk hidup lebih sejahtera, sesungguhnya seiring dengan visi-misi kepala daerah yang termuat dalam RPJMD Kabupataten Teluk Bintuni tahun 2016-2021. Dengan mempertimbangkan potensi, kondisi, permasalahan, tantangan dan peluang yang ada di Kabupaten Teluk Bintuni, maka Visi yang hendak dicapai adalah: Terwujudnya Kabupaten Teluk Bintuni menuju Masyarakat Yang Maju, Produktif dan Berdaya Saing. Pembangunan daerah di Kabupaten Teluk Bintuni diarahkan menggunakan daya dukung sektor pertanian dalam arti luas sebagai motor penggerak potensi daerah serta pemanfaatan sumberdaya alam yang terpadu dan berkelanjutan. Produktif juga berkaitan dengan kondisi 
masyarakat dan kawasan yang memiliki tingkat kesejahteraan yang baik, angka kemiskinan yang menurun, tingkat kesenjangan yang rendah dan pembangunan dapat dirasakan oleh seluruh lapisan masyarakat (RPJMD, 2016). Namun pembangunan di kampung-kampung yang masuk dalam kawasan Cagar Alam Teluk Bintuni menjadi dilematis bagi pemerintah daerah, karena di sisi lain aktivitas berlebihan dalam kasawan konservasi termasuk melanggar peraturan perundang-undangan tentang konservasi sumber daya alam. Permasalahan adanya aktivitas yang cukup intensif yang ditandai dengan adanya perkampungan di dalam kawasan Cagar Alam tentunya akan menjadi ancaman bagi kelangsungan kawasan itu sendiri. Meskipun kondisi kawasan cagar alam teluk bintuni saat ini masih dalam kondisi baik. Akan tetapi dengan melihat dengan berbagai tekanan yang dihadapi, terutama unsur sosial dan ekonomi maka perlu ada upaya antisipasi sedini mungkin.

Upaya penyelesaian masalah tersebut perlu melibatkan semua pihak, terutama masyarakat yang berada di dalam dan sekitar kawasan cagar alam teluk Bintuni. Sejumlah alternatif pemecahan masalah yang bisa dilakukan antara lain (Sihite dkk, 2005) :

1. Penyuluhan dan penerangan yang intensif kepada masyarakat tentang bahaya dari penggunaan bahan kimia terhadap kesinambungan hasil tangkapan dan lingkungan serta melakukan upaya peningkatan pengawasan dan penegakan hukum.

2. Pengaturan penangkapan satwa liar di hutan dengan melibatkan partisipasi masyarakat.

3. Melakukan upaya pemberdayaan masyarakat melalui pelatihanpelatihan dan pembinaan untuk meningkatkan ekonomi masyarakat.
4. Adanya kebijakan pemerintah daerah untuk tidak melakukan penambahan jumlah kampung yang berada dalam kawasan Cagar Alam Teluk Bintuni. Selain itu perlu dibuat Peraturan daerah yang menetapkan kawasan Cagar Alam Teluk Bintuni sebagai kawasan Konservasi.

5. Arah pembangungan pemerintah kabupaten Teluk Bintuni diarahkan agar menjauhi kawasan cagar Alam Teluk Bintuni. Sehingga potensi kerusakan lingkungan akibat pemanfaatan sumber daya alam dalam kawasan dapat ditekan.

\section{Persepsi tentang sosialiasi atau} penyuluhan dari Dinas Kehutanan/ Instansi terkait pengelolaan Kawasan Cagar Alam Teluk Bintuni

Tingginya aktivitas masayarakat di dalam kawasan cagar alam dapat disebabkan oleh rendahnya Pemerintah melalui instansi terkait melakukan sosialisasi kepada masyarakat. Sehingga masyarakat tidak memiliki pemahaman yang baik tentang kawasan cagar alam yang wajib dijaga dan dilestarikan.

Tabel 7. Tanggapan Responden tentang sosialiasi atau penyuluhan dari Dinas Kehutanan/Instansi terkait tentang pengelolaan Kawasan Cagar Alam Teluk Bintuni

\begin{tabular}{|c|c|c|c|c|}
\hline \multirow[b]{2}{*}{$\begin{array}{c}\text { Alternatif } \\
\text { Jawaban }\end{array}$} & \multirow{2}{*}{$\begin{array}{l}\text { Al- } \\
\text { ter- } \\
\text { natif } \\
\text { Skor }\end{array}$} & \multicolumn{2}{|c|}{ Responden } & \multirow{2}{*}{$\begin{array}{c}\text { To- } \\
\text { tal } \\
\text { Skor }\end{array}$} \\
\hline & & $\begin{array}{c}\text { Jum- } \\
\text { lah }\end{array}$ & $\begin{array}{l}\text { Presen- } \\
\text { tase }\end{array}$ & \\
\hline $\begin{array}{l}\text { Sangat } \\
\text { Sering }\end{array}$ & 5 & 0 & $0,00 \%$ & 0 \\
\hline Sering & 4 & 0 & $0,00 \%$ & 0 \\
\hline $\begin{array}{l}\text { Tidak } \\
\text { Tahu }\end{array}$ & 3 & 0 & $0,00 \%$ & 0 \\
\hline Jarang & 2 & 5 & $31,25 \%$ & 10 \\
\hline $\begin{array}{l}\text { Tidak } \\
\text { pernah }\end{array}$ & 1 & 11 & $68,75 \%$ & 11 \\
\hline Total & & 16 & $100 \%$ & 21 \\
\hline
\end{tabular}

Dari hasil penelitian yang tersaji pada Tabel 7, diketahui bahwa $100 \%$ responden mengaku jarang bahkan tidak 
pernah pihak Dinas Kehutanan maupun instansi lainnya melakukan Sosialisasi/ penyuluhan tentang pengelolaan Kawasan Cagar Alam Teluk Bintuni yang selama ini masyarakat tempati. Total skor yang diperoleh pada pernyataan ini adalah 21 , sehingga angka indeks persepsi menjadi $21 / 80 \times 100 \%=26,25 \%$ atau tergolong rendah. Hal ini karena masyarakat merasa tidak ada perhatian sama sekali dari Pemerintah terkait pengelolaan kawasan Cagar Alam Teluk Bintuni. Padahal masyarakat memiliki keinginan yang besar untuk dapat dilibatkan dalam pengelolaan kawasan tersebut.

Kondisi ini senada dengan hasil penelitian di lapangan, dimana 68,75\% responden mengaku tidak pernah dilibatkan oleh instansi terkait dalam pengelolaan kawasan Cagar Alam Teluk Bintuni. Hanya 12,5 \% yang mengaku jarang dan sisanya $18,75 \%$ mengaku ragu-ragu.

Tabel 8. Tanggapan Responden tentang keterlibatan masyarakat dalam pengelolaan Kawasan Cagar Alam

\begin{tabular}{lcccc}
\hline Alternatif & $\begin{array}{c}\text { Al- } \\
\text { ter- } \\
\text { Jawaban }\end{array}$ & \multicolumn{2}{c}{ Responden } & To- \\
\cline { 5 - 6 } & Skor & $\begin{array}{c}\text { Jum- } \\
\text { Sah }\end{array}$ & $\begin{array}{c}\text { Presen- } \\
\text { tase }\end{array}$ & $\begin{array}{c}\text { tal } \\
\text { Skor }\end{array}$ \\
\hline Sangat & 5 & & $0,00 \%$ & 0 \\
Sering & & & & \\
Sering & 4 & & $0,00 \%$ & 0 \\
Cukup & 3 & 3 & $18,75 \%$ & 9 \\
Jarang & 2 & 2 & $12,50 \%$ & 4 \\
Tidak & 1 & 11 & $68,75 \%$ & 11 \\
Pernah & & & & \\
\hline Total & & 16 & $100 \%$ & 24 \\
\hline
\end{tabular}

Dari Tabel 8 diketahui total skor yang diperoleh dari pernyataan tersebut adalah 24, sehingga angka indeks persepsi menjadi $24 / 80 \times 100 \%=30 \%$ atau tergolong rendah.

\footnotetext{
Persepsi Masyarakat terkait upaya pemeliharaan atau perlindungan hutan secara pribadi/ kelompok atas dasar kesadaran sendiri
}

Minimnya perhatian pemerintah melalui instansi terkait untuk melibatkan masyarakat dalam pengelolaan kawasan Cagar Alam Teluk Bintuni, sehingga mendorong masyarakat untuk melakukan upaya sendiri melalukan perlin-dungan hutan. Meskipun peran serta masyarakat dalam upaya pelestarian hutan tergolong sangat kecil. Upaya yang dilakukan oleh masyarakat hanya bersifat tradisional, karena keterbatasan pengetahuan, pendidikan hingga biaya yang digunakan untuk pelestarian hutan.

Tabel 9. Tanggapan Responden terkait swadaya masyarakat melakukan pelestarian Hutan dalam Kawasan Cagar Alam Teluk Bintuni

\begin{tabular}{|c|c|c|c|c|}
\hline \multirow[b]{2}{*}{$\begin{array}{c}\text { Alternatif } \\
\text { Jawaban }\end{array}$} & \multirow{2}{*}{$\begin{array}{c}\text { Al- } \\
\text { ter- } \\
\text { natif } \\
\text { Skor }\end{array}$} & \multicolumn{2}{|c|}{ Responden } & \multirow{2}{*}{$\begin{array}{c}\text { To- } \\
\text { tal } \\
\text { Skor }\end{array}$} \\
\hline & & $\begin{array}{c}\text { Jum- } \\
\text { lah }\end{array}$ & $\begin{array}{c}\text { Presen- } \\
\text { tase }\end{array}$ & \\
\hline Sangat & 5 & & $0,00 \%$ & \\
\hline Sering & & & & 0 \\
\hline Sering & 4 & 3 & $18,75 \%$ & 12 \\
\hline Cukup & 3 & 0 & $0,00 \%$ & 0 \\
\hline Jarang & 2 & & $0,00 \%$ & 0 \\
\hline Tidak & 1 & 13 & $81,25 \%$ & \\
\hline Pernah & & & & 13 \\
\hline Total & & 16 & $100 \%$ & 25 \\
\hline
\end{tabular}

Berdasarkan hasil penelitian yang tertuang pada Tabel 9 terungkap bahwa $81,25 \%$ mengaku tidak pernah melakukan upaya pemeliharaan dan perlindungan Hutan dalam kawasan Cagar Alam Teluk Bintuni. Sementara hanya $18,75 \%$ yang mengaku sering melakukan upaya pelestarian Hutan.Total skor dari pernyataan tersebut adalah 25 , sehingga angka indeks persepsi terhitung $25 / 80 \times 100 \%=31,25 \%$ atau masih tergolong rendah.

\section{Aktivitas Ekonomi Masyarakat dalam Kawasan Cagar Alam Teluk Bintuni}

Berdasarkan data Statistik tercatat sebanyak 312 jiwa mendiami tiga kampung di Distrik Wamesa yang secara geografis berada dalam Kawasan Cagar Alam Teluk Bintuni. Dengan kondisi tersebut, maka secara otomatis sebagian 
atau seluruh aktivitas masyarakat berada dalam kawasan Cagar Alam, termasuk aktivitas ekonomi.

Adanya fasilitas jaringan jalan, permukiman, dan fasilitas sosial ekonomi pendukungnya yang ada di kawasan Cagar Alam Teluk Bintuni, mengindikasikan bahwa kawasan hutan ini relatif terbuka bagi masuknya kegiatan pembangunan. Adanya fasilitas permukiman penduduk yang berada di kawasan hutan serta budidaya pertanian di kawasan hutan, lambat laun seiring pertumbuhan penduduk tentu bisa berdampak terhadap berkurangnya luas hutan.

Berdasarkan wawancara di lapangan, pada umumnya masyarakat melakukan aktivitas bertani/ berkebun, mencari kayu bakar, memancing, menangkap udang dan kepiting di dalam kawasan cagar alam Teluk Bintuni. Aktivitas tersebut sudah biasa dilakukan guna mencukupi kebutuhan masyarakat sehari-hari.

Tabel 10. Tanggakan Responden tentang Aktivitas Masyarakat dalam Kawasan Cagar Alam Teluk Bintuni

\begin{tabular}{clcccc}
\hline \multirow{2}{*}{ No } & \multicolumn{1}{c}{ Pertanyaan } & \multicolumn{2}{c}{ Jawaban } & \multicolumn{2}{c}{ Presentase } \\
\cline { 3 - 6 } & $\begin{array}{l}\text { Apakah pekerjaan bapak/ibu terkait dengan } \\
\text { keberadaan hutan mangrove dalam kawasan } \\
\text { cagar alam teluk Bintuni? }\end{array}$ & 14 & 2 & $87,50 \%$ & $12,50 \%$ \\
\hline 2 & $\begin{array}{l}\text { Apakah ada ijin resmi terkait aktivitas yang } \\
\text { bapak/ibu lakukan dalam kawasan Cagar Alam? }\end{array}$ & 0 & 16 & $0,00 \%$ & $100,00 \%$ \\
\hline
\end{tabular}

Terkait jenis pekerjaan, dari Tabel 10 terlihat bahwa $87,5 \%$ responden menjawab bahwa pekerjaan atau mata pencaharian masyarakat sangat terkait dengan kawasan Cagar Alam Teluk Bintuni. Hanya $12,5 \%$ responden yang menjawab tidak ada kaitannya dengan kawasan tersebut. Jenis pekerjaan yang digeluti masyarakat, pada umumnya adalah mencari ikan, udang dan kepiting $(43,75 \%)$ dan bertani/ berkebun $(37,5 \%)$.
Meskipun tempat matapencaharian masyarakat merupakan Kawasan Cagar Alam yang sangat dilindungi oleh Pemerintah, namun untuk melakukan aktivitas di dalamnya masyarakat tidak memerlukan ijin resmi dari Instansi terkait. Dari hasil penelitian, $100 \%$ responden menjawab tidak ada ijin resmi untuk melakukan aktivitas di dalam kawasan Cagar Alam Teluk Bintuni.

Tabel 11. Frekuensi masyarakat melakukan aktivitas dalam kawasan Cagar Alam Teluk Bintuni dan Tingkat pendapatan

\begin{tabular}{|c|c|c|c|}
\hline No. & Pertanyaan & $\begin{array}{c}\text { Jumlah } \\
\text { Responden }\end{array}$ & $\begin{array}{l}\text { Presen- } \\
\text { tase }\end{array}$ \\
\hline \multirow[t]{6}{*}{1.} & Kapan biasanya Bapak/Ibu melakukan aktivitas di dalam hutan? & & \\
\hline & $\checkmark \quad$ Setiap hari dalam seminggu & 9 & $56,25 \%$ \\
\hline & $\checkmark \quad$ Seminggu sekali dalam sebulan & 4 & $25,00 \%$ \\
\hline & $\checkmark \quad$ Dua minggu sekali dalam sebulan & 1 & $6,25 \%$ \\
\hline & $\checkmark \quad$ Satu bulan sekali & & $0,00 \%$ \\
\hline & $\checkmark \quad$ Tidak tentu dalam sebulan & 2 & $12,50 \%$ \\
\hline \multirow[t]{2}{*}{2.} & $\begin{array}{l}\text { Berapa besar pendapatan Bapak/Ibu sebulan dari aktivitas yang dil- } \\
\text { akukan dalam kawasan cagar alam? }\end{array}$ & & \\
\hline & $\checkmark \quad<$ Rp. $1.000 .000,-$ per bulan & 2 & $12,50 \%$ \\
\hline
\end{tabular}




\begin{tabular}{cccrc}
\hline No. & \multicolumn{1}{c}{ Pertanyaan } & $\begin{array}{c}\text { Jumlah } \\
\text { Responden }\end{array}$ & $\begin{array}{c}\text { Presen- } \\
\text { tase }\end{array}$ \\
\hline$\checkmark$ & Rp. 1.000.000,- s.d. Rp. 4.000.000,- per bulan & 9 & $56,25 \%$ \\
\hline$\checkmark$ & Rp. 4.000.000,- s.d. Rp. 5.000.000,- per bulan & 3 & $18,75 \%$ \\
\hline$\checkmark$ & $>$ Rp. 5.000.000,- per bulan & 2 & $12,50 \%$ \\
\hline
\end{tabular}

Berdasarkan hasil penelitian yang disajikan pada Tabel 11 terlihat bahwa aktivitas masyarakat dalam kawasan cagar alam teluk Bintuni sangat tinggi. $56,25 \%$ responden mengaku setiap hari melakukan aktivitas dalam hutan cagar alam, 25\% mengaku sebanyak seminggu sekali. Semen-tara sekitar $12,5 \%$ responden yang mengaku tidak tentu waktunya melakukan aktivitas dalam kawasan Cagar Alam Teluk Bintuni.

Terkait pendapatan, $56,25 \%$ responden mengaku memiliki pendapatan sekitar Rp. 1.000.000,- s.d. Rp. 4.000.000,- per bulan. Dan sebanyak $31,25 \%$ responden yang mengaku memiliki pendapat lebih dari Rp. 4.000.000,-. Meskipun demikian sebagian besar masyarakat mengaku bahwa pendapatan yang diperoleh dari aktivoitas yang dilakukan dalam kawasan Cagar Alam masih kurang. Namun demikian penghasilan yang diperoleh hanya mampu untuk memenuhi kebutuhan makanan seharihari. Jika ada kelebihan akan digunakan untuk membeli pakaian dan memperbaiki rumah atau tempat tinggal mereka.

Aktivitas masyarakat di dalam kawasan cagar alam Teluk Bintuni diperkirakan akan terus mengalami peningkatan. Hal ini diakibatkan terjadinya penambahan penduduk tiap tahunnya. Berdasarkan hasil wawancara, $100 \%$ responden mengaku setiap tahun kampung yang ditinggali mengalami penambahan penduduk sekitar 25 - 45 orang/ tahun.

Kondisi ini tentunya dikhawatirkan akan mengancam kelestarian keberadaan kawasan cagar alam Teluk Bintuni. Oleh karena itu diperlukan upaya-upaya yang arif dan bijak dalam pelestarian hutan tanpa harus merugikan kepentingan masyarakat yang sudah turun temurun tinggal di kawasan tersebut.

\section{Peran Serta masyarakat Dalam Peles- tarian Cagar Alam Teluk Bintuni}

Berdasarkan kajian analisis yang telah dilakukan, maka perkembangan aktivitas masyarakat di dalam kawasan hutan Cagar Alam Teluk Bintuni berpotensi untuk meng-ganggu fungsi Hutan itu sendiri. Gangguan yang terjadi akibat dari perkembangan aktivitas masyarakat, seperti kegiatan perbu-ruan, pertanian, perkembangan sarana prasanan pemukiman (jalan, jaringan listrik, fasilitas pendidikan, kesehatan dan lainnya), maupun aktivitas sehari-hari masyarakat (mencari kayu bakar, mencari ikan, kepiting, udang, menebang pohon dan lainnya). Hal ini diperparah adanya temuan penambahan pen-duduk yang cukup tinggi di kampung-kam-pung yang berada dalam kawasan cagar alam tersebut.

Berdasarkan aktivitas yang berpotensi mengganggu kelestarian fungsihutan tersebut di atas merupakan fenomena perilaku masya-rakat setempat yang ditelitidalam studi dan sekaligus merupakan indikasi awal terganggu-nya fungsi $\mathrm{Hu}-$ tan Cagar Alam. Padahal amanat undang-undang kehutanan bahwa di kawasan yang berfungsi lindung tidak boleh dilakukan aktivitas yang dapat merusak fungsi kawasan tersebut.

Oleh karana itu perlu dilakukan upaya pelestarian cagar alam Teluk Bintuni dengan melibatkan masyarakat sekitar. Namun sangat disayangkan peran pemerintah yang mengu-rusi pelestarian kawasan hutan masih sangat rendah. Hal 
ini berdasarkan pengakuan masyarakat yang menyebutkan bahwa Peme-rintah melalui instansi terkait jarang melaku- kan sosialisasi kepada masyarakat tentang Kawasan Cagar Alam Teluk Bintuni.

Tabel 12. Tanggapan Responden tentang Pelestarian Hutan Cagar Alam Teluk Bintuni

\begin{tabular}{|c|c|c|c|c|c|c|c|}
\hline \multirow[b]{2}{*}{ No. } & \multirow[b]{2}{*}{ Pertanyaan } & \multicolumn{3}{|c|}{ Jawaban Responden } & \multicolumn{3}{|c|}{ Presentase } \\
\hline & & Ada & $\begin{array}{c}\text { Tidak } \\
\text { Ada }\end{array}$ & $\begin{array}{l}\text { Tidak } \\
\text { Tahu }\end{array}$ & Ada & $\begin{array}{c}\text { Tidak } \\
\text { Ada }\end{array}$ & $\begin{array}{l}\text { Tidak } \\
\text { Tahu }\end{array}$ \\
\hline 1. & $\begin{array}{l}\text { Apakah ada hukum adat/ kearifan lo- } \\
\text { kal, misalnya patangan, pamali atau } \\
\text { ritual untuk menjaga kelestarian hu- } \\
\text { tan mangrove? }\end{array}$ & 0 & 16 & 0 & $\begin{array}{c}0,00 \\
\%\end{array}$ & $\begin{array}{c}100,00 \\
\%\end{array}$ & $0,00 \%$ \\
\hline 2. & $\begin{array}{l}\text { Menurut Bapak/Ibu, apakah selama } \\
\text { ini ada tindakan yang dilakukan oleh } \\
\text { masyarakat untuk melakukan } \\
\text { pemelihraan sebagai upaya menjaga } \\
\text { kelestarian hutan mangrove (misal } \\
\text { menanam mangrove, melarang per- } \\
\text { buruan, dll)? }\end{array}$ & 1 & 8 & 7 & $\begin{array}{c}6,25 \\
\%\end{array}$ & $50,00 \%$ & $43,75 \%$ \\
\hline 3. & $\begin{array}{l}\text { Menurut Bapak/ Ibu, apakah ada ken- } \\
\text { dala / hambatan dalam pelaksanaan } \\
\text { upaya pelestarian hutan mangrove? }\end{array}$ & 0 & 14 & 2 & $\begin{array}{c}0,00 \\
\%\end{array}$ & $87,50 \%$ & $12,50 \%$ \\
\hline 4. & $\begin{array}{l}\text { Sepengetahuan Bapak/ Ibu/ Saudara } \\
\text { apakah ada lembaga dalam bentuk } \\
\text { koperasi atau lainnya yang dikelola } \\
\text { masyarakat yang dilibatkan dalam } \\
\text { pengelolaan Kawasan Cagar Alam } \\
\text { Teluk Bintuni? }\end{array}$ & 0 & 11 & 5 & $\begin{array}{c}0,00 \\
\%\end{array}$ & $68,75 \%$ & $31,25 \%$ \\
\hline
\end{tabular}

Berdasarkan hasil penelitian yang disajikan dalam Tabel 12, diketahui bahwa $100 \%$ responden mengakui tidak ada hukum adat tertentu yang dilakukan untuk menjaga kelestarian hutan Mangrove yang masuk dalam kawasan Cagar Alam Teluk Bintuni. Sehingga masyarakat bebas melakukan aktivitas di dalam kawasan tersebut. Bahkan hutan bagi sebagian masyarakat dianggap sebagai tempat untuk mencari penghasilan tanpa perlu mempedulikan status hutan tersebut.

Terkait upaya masyarakat untuk mela-kukan pelestarian hutan, seperti melaku-kan penanaman pohon mangrove, $50 \%$ res-ponden mengaku tidak pernah dan $43,75 \%$ mengaku tidak tahu. Dan hanya $6,25 \%$ yang mengaku pernah melakukan upaya pelestarian hutan.
Pada dasarnya upaya pelestarian hutan terutama yang masuk dalam kawasan cagar alam perlu dilakukan baik oleh pemerintah maupun masyarakat itu sendiri. Berdasarkan hasil wawancara, $87,5 \%$ responden mengaku tidak ada hambatan dalam upaya pelestarian hutan tersebut. Sedangkan $12,5 \%$ responden mengaku tidak tahu.

Pengelolaan kawasan cagar alam Teluk Bintuni dapat dilakukan oleh kelompok masyarakat, seperti koperasi atau lembaga lainnya. Namun hingga saat ini, $68,75 \%$ responden mengaku belum ada koperasi/ lembaga lain yang dikelola masyarakat terlibat dalam pengelolaan kawasan Cagra Alam. Sementara sisanya, $31,25 \%$ responden mengaku tidak tahu terkait hal tersebut. 
Tabel 12. Tanggapan Responden tentang Pelestarian Kawasan Hutan Cagar Alam Teluk Bintuni

\begin{tabular}{clcccr}
\hline \multirow{2}{*}{ No. } & \multicolumn{1}{c}{ Pertanyaan } & \multicolumn{2}{c}{$\begin{array}{c}\text { Jawaban } \\
\text { Responden }\end{array}$} & \multicolumn{2}{c}{ Presentase } \\
\cline { 3 - 6 } & \multicolumn{1}{c}{ Ya } & Tidak & Ya & Tidak \\
\hline 1. & $\begin{array}{l}\text { Apakah Bapak/Ibu pernah diajak oleh dari pemerintah/ } \\
\text { Dinas Kehutanan untuk menjaga kelestarian Hutan? }\end{array}$ & 3 & 13 & $18,75 \%$ & $81,25 \%$ \\
\hline 2. & $\begin{array}{l}\text { Apakah Bapak/Ibu mengetahui bahwa masyarakat } \\
\text { memiliki hak dan kewajiban dalam pengelolaan kawa- } \\
\text { san cagar alam Teluk Bintuni ? }\end{array}$ & 4 & 12 & $25,00 \%$ & $75,00 \%$ \\
\hline 3. & $\begin{array}{l}\text { Menurut Bapak/ Ibu, apakah masyarakat menghendaki } \\
\text { kelestarian Hutan Mangrove (konservasi)? }\end{array}$ & 16 & 0 & $100,00 \%$ & $0,00 \%$ \\
\hline
\end{tabular}

Dari hasil penelitian pada Tabel 12 . diketahui bahwa pemerintah melalui instansi terkait jarang melibatkan masyarakat dalam upaya menjaga kelesatarian hutan. Sebanyak $81,25 \%$ responden mengaku tidak pernah diajak oleh Dinas Kehutanan atau Instansi terkait untuk menjaga kelestarian hutan. Sementara $18,75 \%$ mengaku pernah diajak untuk menjaga kelesatrian hutan.

Karena kurangnya pengetahuan dan sosialisasi oleh pemerintah, sehingga $75 \%$ responden mengakui tidak mengetahui jika masyarakat memiliki hak dan kewajiban dalam pengelolaan kawasan cagar alam teluk bintuni. Hanya $25 \%$ responden yang mengaku mengetahui hak dan kewajiban tersebut. Meskipun 100\% responden sepakat dan menghendaki adanya kelestarian hutan mangrove yang masuk dalam kawasan cagar alam Teluk Bintuni.

Meskipun masyarakat yang hidup di dalam kawasan Cagar Alam mengaku tidak melakukan upaya pelestarian hutan secara langsung, namun sesungguhnya pola masyarakat menjaga kearifan tradisional/ lokal mendorong perlindungan hutan itu sendiri. Masyarakat yang bermukim di dalam kawasan cagar alam masih memiliki kepercayaan bahwa tempat-tempat tertentu masih dianggap keramat (tempat pamali). Biasanya masyarakat tidak berani atau dilarang memasuki tempat keramat tersebut. Tempat keramat tersebut disebut dengan jer. Misalnya terdapat lokasi, di mana orang di larang mandi, mencari ikan maupun menyebrang. Apabila ada orang yang melanggar larangan tersebut dengan menginjakan kakinya ke dalam air di eilayah jer, maka dipercaya kakinya akan bengkok hingga meninggal dunia. Ada juga kawasan hutan yang dipercaya oleh masyarakat sekitar sebagai tempat yang dikeramatkan atau disebut yok atau yomes. Di tempat tersebut orang juga dilarang memasukinya atau mengambil sesuatu. Pemahaman tradisional tersebut jelas merupakan salahs atu bentuk untuk melindungi kawasan, sehingga tidak dirusak atau dicemari karena dapat mengganggu kelangsungan hidup mereka (Sihite dkk, 2005).

Bentuk lain yang dilakukan masyarakat dalam melindungi kawasan hutan terlihat dari cara pemanfaatan sumber daya alam yang masih sangat tradisional misalnya, pengambilan kepiting/ karaka. Dalam proses pengambilan karaka, masyarakat biasanya tidak mengambil seluruh jumlah karaka dalam satu liang (lubang) dengan pertimbangan karaka yang ditinggalkan bisa berkembang biak. Selain itu dalam memanen hasil pohon sagu, masyarakat adat wamesa hanya menebang pohon sagu yang tua dengan indikator telah berbunga. Prilaku masyarakat dalam pemanfaatan sumber daya alam sesungguhnya telah sejalan dengan prinsip-prinsip konservasi. Artinya, masyarakat setempat dalam 
memanfaatkan kawasan cagar alam Teluk Bintuni sangat memperhatikan regenerasi dan kemampuan daya dukung ekosistem, sehingga kearifan tradisional tersebut harus dipelihara dan dipertahankan keberadaannya (Sihite dkk, 2005).

\section{Harapan Masyarakat yang Berada Dalam Kawasan Cagar Alam Teluk Bintuni}

Berdasarkan hasil wawancara dengan para responden, bahwa masyarakat yang bera-da dalam kawasan Cagar Alam Teluk Bintuni mengharapkan beberapa hal, antara lain:

1. Ikut terlibat dalam setiap kegiatan yang dilaksanakan dalam kawasan Cagar Alam Teluk Bintuni.

2. Ikut aktif dalam melestarikan kawasan Cagar Alam Teluk BIntuni, tetapi tidak melupakan kebutuhan hidup masyarakat sehari-hari. Karena ketergantungan masyarakat untuk memenuhi hidup terha-dap keberadaan Kawasan Cagar Alam Teluk Bintuni masih sangat tinggi.

3. Masyarakat masih diijinkan melaksanakan kegiatan/ aktivitas ekonomi dalam kawasan, berupa:

a. Melakukan penangkapan hasilhasil perikanan seperti ikan, udang, karaka, siput atau bia dan hasil laut lainnya dengan cara sederhana dan tidak merusak lingkungan.

b. Melakukan usaha budidaya pertanian/ berkebun.

c. Melakukan pemanfaatan kayu mangi-mangi untuk kayu bakar sendiri (bukan untuk dijual)

d. Melakukan kegiatan perburuan hewan atau satwa liar seperti buaya, rusa, babi hutan dan burung

4. Diharapkan adanya perhatian serius dari pemerintah dalam upaya meningkatkan ekonomi masyarakat, seperti bantuan pemerintah, pelatihan - pelatihan, penyu-luhan, pembinaan dan pendampingan.

5. Diharapkan adanya peningkatakan infra-struktur dan fasilitas umum (jalan, jemba-tan, pendidikan, kesehatan dan ekonomi) untuk menunjang pemenuhan kebutuhan dasar masyarakat.

Menurut, Sihite (2005), bahwa berdasarkan sejarah dan historikal pemanfaatannya Cagar Alam Teluk Bintuni termasuk dalam kategori kawasan yang telah dimanfaatkan namun belum menimbulkan kerusakan lingkungan yang luas. Sehingga untuk mempertahankan keberadaan Cagar Alam Teluk Bintuni perlu adanya penanganan yang serius saat ini dan ke depan. Penangangan yang serius penting untuk menghindari pemanfaatan yang tidak terken-dali dan hanya mengejar keuntungan semata (rent seeker) yang dapat menyebabkan kerusakan lingkungan lebih besar dari kondisi saat ini sehingga akan memberikan efek multiplier dalam bentuk kemiskinan dan kepunahan ekosistem CATB. Oleh karena itu mekanisme penanganannya harus didasarkan pada prinsip pengelolaan konservasionis dengan basis pada peningkatan kesejahteraan masyarakat.

\section{KESIMPULAN}

\section{Kesimpulan}

Berdasarkan hasil penelitian dapat disimpulkan bahwa:

1. Persepsi masyarakat adat atas penetapan kawasan konservasi cagar alam Teluk Bintuni yang dikategorikan sebagai berikut:

a. Persepsi terkait keinginan keterlibatan masyarakat dalam pelestarian hutan di kawasan cagar alam Teluk Bintuni tergolong sangat tinggi $(83,75 \%)$; 
b. Persepsi terhadap ketergantungan masyarakat terhadap kawasan Cagar Alam Teluk Bintuni tergolong sangat tinggi $(91,25 \%)$;

c. Persepsi terhadap aktivitas masyarakat di dalam kawasan cagar alam Teluk Bintuni tergolong rendah $(30 \%)$;

d. Persepsi terkait Larangan Pemerintah terhadap masyarakat yang melakukan aktivitas (menebang pohon, berladang, memancing, berburuh) di dalam kawasan cagar alam teluk Bintuni tergolong sedang (60\%);

e. Persepsi terhadap peningkatan pembangunan di dalam kawasan cagar alam Teluk Bintuni tergolong sedang $(43,75 \%)$;

f. Persepsi tentang sosialiasi atau penyuluhan dari Dinas Kehutanan/ Instansi terkait pengelolaan Kawasan Cagar Alam Teluk Bintuni tergolong rendah $(26,25 \%)$;

g. Persepsi Masyarakat terkait upaya pemeliharaan atau perlindungan hutan secara pribadi maupun kelompok atas dasar kesadaran sendiri tergolong rendah $(31,25 \%)$.

2. Aktivitas ekonomi yang dilakukan masyarakat adat di dalam kawasan konservasi Cagar Alam Teluk Bintuni sangat tinggi. Hal ini terbukti dari 56,25\% responden melakukan aktivitas dalam hutan cagar alam setiap hari, 25\% seminggu sekali, dan $12,5 \%$ responden tidak tentu waktunya. Terkait jenis pekerjaan menunjukan bahwa $87,5 \%$ responden menjawab bahwa pekerjaan atau mata pencaharian masyarakat sangat terkait dengan kawasan Cagar Alam Teluk Bintuni. Hanya 12,5\% responden yang menjawab tidak ada kaitannya dengan kawasan tersebut.
Jenis pekerjaan yang digeluti masyarakat, pada umumnya adalah nelayan (ikan, udang dan kepiting) $(43,75 \%)$ dan Bertani atau berkebun $(37,5 \%)$.

3. Harapan atau keinginan masyarakat adat atas penetapan kawasan Cagar Alam Teluk Bintuni, yaitu:

a. Dilibatkan secara aktif dalam kegiatan-kegiatan terkait Kawasan Cagar Alam Teluk Bintuni.

b. Masih diijinkan melakukan aktivitas ekonomi di dalam kawasan, seperti berburuh, berkebun, menangkap ikan dan lainnya.

c. Adanya perhatian pemerintah dalam upaya peningkatan ekonomi masyarakat yang berada dalam kawsan.

d. Peningkatan Infrastruktur dan fasilitas umum lainnya, namun dengan tetap menjaga kelestarian lingkungan/ hutan dalam kawsan cagar alam Teluk Bintuni.

\section{Saran}

Dari hasil penelitian dan pembahasan yang dilakukan, maka peneliti memberikan saran-saran sebagai berikut:

1. Perlu dilakukan sosialisasi atau penyuluhan secara rutin tentang perlindungan dan pelestarian kawasan Cagar Alam Teluk Bintuni. Dan masyarakat perlu dilibatkan secara aktif dalam kegiatan-kegiatan pengelolaan Kawasan.

2. Untuk meningkatkan ekonomi masyarakat, maka perlu adanya bantuan dan bimbingan teknis kepada masyarakat yang sebagian bermata pencaharian sebagai petani, nelayan, berburu dan meramu.

3. Masyarakat di dalam kawasan diharapkan mampu menjaga dan melindungi Kearifan lokal sebagai upaya melindungi dan melestarikan Kawasan Cagar Alam Teluk Bintuni. 
4. Pemerintah daerah diharapkan dapat segera membuat regulasi (perda dan pebup) tentang perlindungan Kawasan Cagar Alam Teluk Bintuni.

\section{DAFTAR PUSTAKA}

Adrianto, Bowo. (2006). Persepsi dan Partisipasi Masyarakat terhadap Pembangunan Prasarana Dasar Permukiman yang Bertumpu pada Swadaya Masyarakat di Kota Magelang. Tesis. UNDIP: Semarang

Aruniastuti, N. (2013). Bahaya Plastik Terhadap Kesehatan dan Lingkungan. Swara Patra: Jakarta

Ghufran, H. (2012). Ekosistem Mangrove : Potensi, Fungsi, dan Pengelolaan. Rineka Cipta: Jakarta

Hess, S., Larsen, S.N., Leisher, C., (2011). Analisis Tren Monitoring Persepsi di Kawasan Konservasi Laut Daerah Misool dan Kofiau, Raja Ampat.Program Kelautan Asia Pasifik. The Nature Conservancy.

Keraf, A.S. (2010). Etika Lingkungan Hidup. Penerbit Buku Kompas: Jakarta.

Kusmana, C. Onrizal, dan Sudarmadji. (2003). Jenis-jenis pohon manggrove di Teluk Bintuni Papua. Fakultas Kehutanan. I TB: Bogor.

Malak, Stephanus. (2006). Kapitalisasi Tanah Adat. Yayasan Bina Profesi Mandiri: Bandung.

Sihite, Richard, (2000). Tourism Industry (Kepariwisataan), SIC: Surabaya SIC.

Sihite, Jamartin. (2005). Masyarakat dan Cagar Alam Teluk Bintuni, Antara Fakta dan Harapan. The Nature Conservancy (TNC), Southeast Asia Center for Marine Protected Areas (SEA CMPA) bekerja sama dengan Lembaga Penelitian Universitas Trisakti. Jakarta.
Suryono, Agus. (2001). Teor idan Isu Pembangunan. Universitas Malang Press: Malang.

Yuwono, Edi. (2001). Handbook Fisiologi Hewan. Fakultas Biologi. UNSOED: Purwakarta.

Undang-Undang RI Nomor 5 Tahun 1990 Tentang Konservasi Sumber Daya Alam Hayati dan Ekosistem.

Undang-Undang RI Nomor 21 Tahun 2001 Tentang Otonomi Khusus Bagi Provinsi Papua dan Papua Barat.

Undang-undang Nomor 32 Tahun 2009 tentang perlindungan dan pengelolaan lingkungan hidup.

Undang - undang nomor 41 tahun 1999 Tentang Kehutanan.

Peraturan Pemerintah Nomor 28 tahun 2011 tentang Pengelolaan Kawasan Suaka Alam dan Kawasan Pelestarian Alam.

SK Menteri Kehutanan nomor: 3121/Menhut-VII/KUH/2014 tanggal 24 April 2014. 